\title{
Consumer Innovativeness in Food Industry: From Literature Review Some Indications for Business Practices
}

\author{
Pierluigi Passaro ${ }^{1} \&$ Sergio Salomone ${ }^{1}$ \\ ${ }^{1}$ Università degli Studi di Bari Aldo Moro, Bari, Italy \\ Correspondence: Pierluigi Passaro, Università degli Studi di Bari Aldo Moro, Bari, Italy.
}

Received: December 30, 2016

Accepted: January 31, 2017

Online Published: February 24, 2017

doi:10.5430/ijba.v8n2p10

URL: http://dx.doi.org/10.5430/ijba.v8n2p10

\begin{abstract}
Objectives. Through the analysis of literature, the evolution of consumer's behaviour is traced, although with broad strokes, with the purpose of outlining the consumer innovativeness related to the sector, in anticipation of the imminent and relevant innovations in food field. Final objective is that of highlighting the principal trends which determine the modern consumer's choices in food sphere.
\end{abstract}

Methodology. The explorative-type research is essentially based on a systematic analysis of literature in theme of bent to innovation in the consumer's behaviour.

Findings. The trend which is changing the attitude to create innovative products in food field will be determined not only by the changes in the consumer's behaviour but above all by the necessity of including such changes in the innovation process, realized by companies.

Research limits. The objective difficulty in the identification of a unanimous definition of innovation does not allow to be able to carry out such an empirical survey to measure the consumer innovativeness, especially in food field.

Practical implications. The deep changes intervened in the life system of consumers on the one hand, and the succeeding each other of events that have profoundly conditioned the agro-food sector on the other hand, have been subjects of studies to understand the new approach of consumers to the food offer, useful for the companies in the definition of product innovation politics.

Originality of the study. The limited literature in the field of consumer innovativeness, much more in the agro-food field, makes the present research original in its attempt of theoretical systematization of concept of bent to consumer's innovation in food field.

Keywords: consumer innovativeness, agro-food, innovation, consumer behaviour

\section{Introduction}

Through the last decades, several studies have tried to connect some personal characteristic with the adoption of new products, included the social-demographic characteristics (Hirunyawipada, Paswan, 2006; Im et al., 2007), the inner innovativity of the consumers (Cotte, Wood, 2004), the innovation-specific dominion (Goldsmith e Hofacker, 1991), the opinion leadership (Summers, 1971; Ruvio, Shoham, 2007), and the involvement with the product (Goldsmith et al., 1998; Wang et al., 2006). In the food context, the social representation of new products has been recently identified as important predictor in the behaviour of adoption of new products (Backstrom et al., 2004; Huotilainen et al., 2006).

Therefore, great interest emerges about the innovative behaviour of consumers, with specific reference to the agro-food sector, which effectively is noticed more and more subject to the innovation.

Infact, the themes of sustainability, of the fight against the wastes, of trackability and of food security find nowadays answer in the technologies (more and more nano and more and more smart), in the socalled app, in the big data, that is in the principal drivers of innovation which ride between company and consumer.

The Big Players, so as the great international investors, and thousands of startups all over the world are defending (and developing) the defined sector of Internet of Food or of Food Tech, destined to grow exponentially in the next years, considering the fact that it impacts with the greatest world economical activity (just that linked to the agro-food). 
In the present research, then, the evolution of consumer's behaviour is traced, though with broad strokes, in food sphere through an analysis of litrature, with the aim of tracing the consumer innovativeness related to the sector (Venkatraman, 1991; Goldsmith, Hofacker, 1991; Roehrich, 2004; Dobre et al., 2009; Banterle et al., 2011), in anticipation of the more and more imminent and relevant innovations in food field (among which it is quoted, for example, precision agriculture, innovations and evolutions in the world of hydroponic, $3 \mathrm{~d}$ printers for food, hand molecular sensors which show the content of a food, new models and platforms of e-commerce in food, new communication systems, promotion, improvement of products, territories or supply chain, smart labels for the trackability of products or indication of their content, applications to reduce the wastes in every passage of the supply chain, systems of cognitive cooking, smart kitchen), highlighting so the principal trends that determine the choices of the modern consumer in food sphere.

\section{The Agro-food Sector in the Actual Scenario}

\subsection{General Profiles through Some Sector Data}

The reason of the renewed interest for the phenomenon "consumption" in the sphere of the economy lies in the evolution of the modern agro-food system, and in the growing awareness of the importance of consumptions dynamics in dictating the rythms of the system development and in tracing its developmental lines. In other words, the phenomenon consumption appears today more able to influence (as well as to be influenced by) the behaviour of operators in economical system (Costa et al., 2004).

The relative stationarity of growing rate of food consumption in the advanced societies and the growing opening of markets have undoubtedly increased the level of competition among companies, exacerbating the fight for the conquer of market room. At the same time it emerges clearly how the consumer of advanced societies shows more and more various and different needs which push the companies to the research of new products, giving birth to a strong dynamicity in the inner of individual commodities sectors (Banterle et al., 2011).

All this makes more and more urgent the necessity of having at disposal reading-keys of modern dynamics of consumptions, suitable to catch the possible reflections about the structural, strategical and organizational arrangement of companies system, considering also the peculiarities of food consumption, that assigns to the economical moment a deep social meaning.

In fact, the food product reflects more than any other the social and cultural values of consumers, and its essential, and inalienable for human life, function, as well as the intimate link which is established between man and nature just through food, make it a specific product whose consumption touches not only the economical sphere but also those nutritional, edonistic, social and symbolic ones.

The analysis of available statistic information highlights how today our Country has reached the so called "fullness phase", in which the food basic needs are, by then, even if only on average, satisfied, or rather in which the nutritional availabilities have exceeded the physiological necessities of the population, such as to determine spread phenomena of over-diet and waste.

Examining some sector data, the year 2014 has represented "the year zero" of the italian agro-food sector, which, with a turnover of 132 billions, more than 58 thousand companies, 385 thousand direct person responsible employed in the agro production, is the second compartment of manufacture. A years of bend, in fact, the fall of food consumptions of Italians stops, and from 2014 on they return flat $(-0,1 \%)$. Positive sign for the production of agro-industry $(+0,6 \%)$ and, obviously, but with reduced sped, also the export $(+3,1 \%)$.

In 2015 the growth of consumptions has consolidated, $(+0,3 \%)$, of production $(+1,1 \%)$ and even of export $(+5,5 \%)$, positive data for the first time from the beginning of the crisis. But several critical factors influence the evaluation of the sector's future.

The exports grow but slow down the run compared to the past: $+3,1 \%$ after $+5,8 \%$ of $2013,+7 \%$ of 2012 and $+10 \%$ of 2011. But it still travels with double speed compared to the overall one of the Country $(+1,5 \%)$. One trend which takes the overall fee 2014 to about 27 billions of euro. The relevance of exports on the food turnover has, in 10 years, grown of almost $50 \%$, passing from $14 \%$ of 2004 to $20,5 \%$ of 2014 . But Italy is still far from competitors such as Spain (22\%), France (28\%), and above all Germany (32\%).

The most interested Countries to the made in Italy food products (in 2014) are those UE (+3,6\%). Outside of Europe, China grows again $(+5,3 \%)$, while the embargo effects and the Pil moving back streamline Russia, with $+3,9 \%$, which anticipate a more marked decelaration in the long period.

Among the "maximum weights" of our export, stationary remains Germany ( $+0,5 \%)$, very good the USA ( $+6,5 \%)$, 
third outlet of national "food and drink" (and first for the wine), although they have the not enviable record regarding the adulteration and Italian sounding (which globally removes to our sector about 60 billions of euro every year): in the USA, in fact, only 1 food product out of 8 among those sold as Made in Italy is really such.

Then, despite the crisis, the demand of made in Italy food is growing. The central ring of the filiera is just the industry. If it has been possible to withstand the crisis better than the manifacture in its whole facing production, export and employment, it is due not only to the anticyclic structural capacities, but alto to the constant investments, either of process or of product, which have allowed to defend competitivity, margins of contribution and offer updating, ensuring thus a positive "fall out" either at source or downstream.

\subsection{The Agro-food System and the Model of Food Consumption}

The Agro-food System is that whole of activities that, inside a Country and in a determined historical moment, contribute to the satisfaction of population's diet function. In this way the food consumption, in key of "agro-food economy", must be considered as interacting with the other components of the same system.

Compared to the concept of agribusiness, which has as purpose that of describing and quantifying the effects of insertion of agriculture in the sphere of developed economies, and that then represents a way to study the problems of the agricultural sector and of the farm in a wider context, the use of concept of agro-food concept makes necessary to internationalize the consumption dimension, which must be examined in its interrelations with the other components of the system and not as a "datum", from the outside determined, for the system of the companies.

In short, this means that, to understand the consumption changes, it is necessary to consider the whole of producers and consumers as different elements of the same integrated system, a system which produces at the same time consumer goods and models of behaviour and life inside of relationship of mutual interaction between production and consumption. The consumption then becomes a phase of the wider process of transformation and improvement that occurs inside the agro-food system: then, to analyze the principal changes in consumptions it is necessary to take into consideration even the existed changes in the companies system, in the awareness that the production sphere and the consumption sphere interact, and that not always it is easily understandable the cause-effect relationship that occurs, as it is seen also from the debate about the crisis of fordian model and the rise of flexible production model.

The reference to the concept of Model of Food Consumption constitutes a possible "socio-economical" answer to the reading of phenomenology of food consumptions, which allows to exceed the analysis of data about what is consumed to go to the root of the question, trying to highlight the determining of the recent evolution and of possible developments of food consumptions. The model of food consumption, in fact, "refers to the way men organize themselves to consume....., to their food practices, to nature and quantity of consumed foods" (Malassis, Padilla, 1986); then, it "is considered as a social fact" (Malassis, Padilla, 1986), in the meaning that it must be interpreted as reflex of social conditions of production and consumption.

The social conditions of production are besides defined by the level of technology, by the capacity of production of agriculture and agroindustry, by the structure of relations between industry and distribution and by the relative forms of organization, while the social conditions of consumption are defined mainly by the relations of production and among the social classes, by the allocation and evolution of incomes, by the agro-food politics, by the relative level of prices, by the urbanization degree, by social conditions of work, by free time, by consumption forms (individual or collective). The model of food consumption is considerable, therefore, as the result of characteristics of agro-food system and of the society ones (Steenkamp et al., 1999).

From this definition, the analysis object results to be enriched compared to the traditional one, that referred to the "nature and quantity of consumed foods" (anyway not only to expense and quantity but also to nutritional diet), to be extended to other aspects which constitute the main characters of model of food consumption, and that is:

- The analysisi of socio-economical Unities of consumption (not necessarily coincident with the family) which represent "the way men organize socially, in the sphere of little combinations, to consume " (Malassis e Padilla, 1986);

- The combination of food practices developed in the sphere of such unities, which go from the supply to the elimination of rubbish through the preservation and stocking, the foods preparation, the food organization.

From these two important implications for the analysis of the food consumptions derive. The first refers to the fact that the consumption must be interpreted no more as a singular act but as a process, an activity which includes more steps. The second regards the necessity of increasing the range of explicative factors to take in exam: in the sphere of the flowing societies, in fact, decreases the influence of the factors linked to the capacity of food supply (which 
depends in its turn on the capacity of internal production and of export) and to the power of consumption, depending on the relations of production (access to production means and/or to the purchasing power and their distribution), while particular importance has to be attributed to the factors that determine the objective conditions of food consumption as much as to the cultural factor, which determine the subjective, or "of freedom" sphere of consumer (Padilla, 1992).

\subsection{Principal Variables which Influence the Food Consumptions}

The food industry has become in the last decades the linchpin of the productive component of filiere and of agro-food systems of developed Countries, assuming a central position either in comparison with the final consumption or with the farm offer above all because of the greatest companies, often international; so that, apart from increasing its own power towards the farm sector, the industry assumes a noticeable power of conditioning even towards the consumers, contributing to determine an homogenization of tastes and a standardization of consumptions (and even their internalization). Such behaviours are thus able to influence the structure itself of consumer's preferences, intervening on his/her informative set and on the dynamics of prices related to consumption (Miele, Parisi, 2000; Fotopoulos et al., 2003).

The variables that influence the structure and evolution of food consumptions derive in their turn from a whole of changes that can be brought back to two great categories, inherent the one in the socio-economical sphere and the other in the socio-cultural sphere, but that anyway are reciprocally linked and interact in the determination of consumption aptitudes (Capitanio et al., 2009; Fortuin e Omta, 2009; Kuhne et al., 2010).

With broad strokes it is possible to affirm that the socio-economical variables define, inside a high-income society, the objective conditions of consumption, depending on the technical-economical and organizative condition, and particularly on work (Gatignon, Robertson, 1991; Rogers, 1995; Steenkamp et al., 1999). In other words, it deals with the ties which derive from the production model and which determine the borders of the circle of consumer's freedoms, in whose sphere the socio-cultual variables (food behavious, psycho-ensorial sensitivity, rites, habits, myths, symbols, codes) guide the explication of choice possibility (Padilla, 1992). As a consequence, the "cultural" motivation will have to be particularly deep to lead to changes in the consumption behaviour to an opposite direction compared to the socio-economical factors (Seyfang, 2006; Dobson e Bell, 2006).

The first group of variables, which derives from the characteristics of productive infrastructure and from the organization of work and family as unity of ground consumption, contributes to define the combination of objective ties to the consumer's actitivity.

One first great category refers to the changes in the work organization, which produce effects on food consumption, such as:,

- The demand of a "lighter" food system, determined by the existence of a workforce more and more tertiarized;

- The deep renovation of familiar times and the recollocation of foods role inside the, not only material but also social, life of the family;

- The (partial) deresponsibilization of the role of woman related to diet, and the reallocation of the phases of process of food consumption among the members of family itself (purchase, preparation of foods, etc.).

One second great category of socio-economical variables is that reportable directly to the changes of demographic type, characterized by the slow down of birth rate of population and, then, of its growing rate. This phenomenon has important consequences on the food consumption, that go the other side of direct effects deriving by the decreasing of "number of mouths to feed". The ageing of population, for example, has important reflexes also on the typologies of consumed products in consideration of the peculiarities of requirements (not only nutritional) of extreme classes of age, but also of the different bend to innovation and more generally of different life styles (Baregheh et al., 2009; Naidoo, 2010).

A third combination of variables of socio-economical type has a more general importance, and is reportable to the change of general conditions of consumption, deriving from phenomena such as urbanization (in its turn strictly connected to the organization of productive activities), the spread of transportation means and the growth of penetration of mass communication means, which tend to increase the interaction among subjects (not only among consumers, but also between consumers and production sphere), widen the circle of knowledges and, then, of possibilities of consumption, and through this way encourage the food change and speed up the adoption of new consumption styles (Grunert et al., 2008).

The second great group of variables refers to the socio-cultural model, that conditions the food behaviours and 
explains how, inside the objective ties of consumption, the consumer's choices explicit themselves. The consumer's attitudes, in fact, as well as deriving from the socio-economical characteristics, reflect also the most general life stle/phylosophy, that is the bundle of aspirations and conduct rules of which everybody equips himself, and that usually are understandable with sociology and psychology tools (Jackson, 2009).

Through the years has changed the consumer's way of behaving toward the phenomenon consumption, passing from "emulative" phases to "mass" phases to "individualistic" phases. In the years of economical boom (1950-60) the first forms of "emulation" consumption begin to appear, at a high component of exteriority and class identification, practically absent during the previous years (Sabbadin, 1990).

The start of urbanization and tertiarized society leads in the 60s' to an extension of style of consumption in the middle-high classes towards all the classes, with the formation of equal behaviours in a market, now become mass, where the needs and the exigences show themselves relatively homogeneous and standardized.

The 70s' instead appear as a period of transition, in which the consumption runs out, grounded on the ostentation of "status symbol" goods and on the loud accumulation, and in which are shown the effects of the oil crisis through the explosion of ecological conscience.

It is above all in the $80 \mathrm{~s}$ ' that the social and cultural factors assume particular relevance in the consumptions dynamics. The consumption behaviours change again, orienting towards the search of individuality. A growing group of consumers stands back more and more from the traditional values addressing to innovative products: the purchase and use places change, the consumers become more selective and more aware of their own independence and appear less conditioned than in the past by shown and èlite emulative factors. The middle class fragments itself and a new bourgeoisie stands out (Sabbadin, 1990; Censis, 1994), with a tendency to the search of "excellence" quality (euphoric consumption), to a personalization of consumptions (individuality about decisions), to a greater variety and diversification of times, ways, places and goods of consumption.

The economic crisi of the first 90s' has speed up the transition process towards a new consumption behaviour which draws inspiration from the paradygm of middle, characterized by a greater affirmation of personality and at the same time by a more moderate cultural attitude, which shows itself in a renewed attention to the relationship quality/price, to the selecton of purchase places, to the choice of products (Censis, 1994). The consumption behaviour, then, becomes more selective and gets out of the mainly aesthetic attributes of the product.

From 2000 on, the factor "crisis" affects again the consumption habits, but, this time, starting from the second half (1). The food consumptions becomes nervous, fragments itself in many snacks which fill time between one mail and another, even because the principal mails give much less satisfaction. But the "problems" of the food consumption come from far away. The crisis has only put a stress on them. Nowadays a family destines to the food less than a fifth of its budget for consumptions. Surely, better than it happens in the North Europe Countries or in the Anglosaxon ones, but objectively always little. In the last decades the weight of food has substantially fallen to other expenses entries' advantage. If this, within limits, is obvious, it becomes worrying when these limits are exceeded. Till some years ago (about 2011), food was risking a dangerous drift towards convenience, that is towards a good that is bought at the lowest price. But food is not any good whatever. It is, on the contrary, as already underlined, a decisive synthesis of cultural, social, aesthetic and environmental values for people's wellness and places' protection.

From this point of view, Italians, at least at level of imaginary, still remain strongly linked to tradition. They are open to the ethnic, but not too much, love fusion food, but not too much, pay attention to calories, but not too much. On the contrary, they privilege tradition, typical product, conviviality, taste, slow more than fast food. The greatest individualization and personalization of consumer's activities which, on the contrary, seem to characterize the modern consumer, lead him to show his decisional subjectivity and independence in more than one direction. Generally, consumer, much more warned and aware than in the past, thanks also to the greater middle level of reached scholarization, and thanks to the increase of information volume (and of related possibilities of access to them), does not answer any more to a need-obligation, but rather to a need-aspiration: consuming is adopting a certain life style. The food tastes (and tastes in general), first prepared to act as signals of social class and status, now show themselves as signals of life style, and consumption becomes a way to communicate it own being: the resources equipment itself can be used to consume products even very different one from the other, in line with the values and priorities of referring or belonging group (Steenkamp, Burgess, 2002; Im et al., 2003; Clark, Goldsmith, 2006; Urala, Lähteenmäki, 2007; Bellows et al., 2010).

Despite the research of greater autonomy and individualism contributes to make much more complex the consumers' context and the individuation of well outlined and stable tendencies, some "new" basic values highlight themselves 
among which the most relevant, above all for the reflexes they are able to exercise on the food consumption sphere, are:

- The tendency to an increase of acceptance of pluralism, either as demonstration of independence of family components, or as acceptance of undercultures and more generally of different cultures;

- The affirmation of an "explorative" and "playing" attitude of consumer, from which are descended an increase of flexibility and desire of variation in every life aspect;

- A renewed and growing attention to future, from which is descended for example a greater care of physical and mental health and a growing sensitivity to environmental problems;

- A research of overcoming the consumption's material contents;

- A "modern" refusal of urban-industrial life style, with a desire of wholesomeness, of opern-air life, of unpolluted nature.

These tendencies have already demonstrated themselves in other Countries, some from much time, and are relatively recent in our Country. Even in this case it is possible to speak about tendency to homogeneization of basic values in high-income societies, not much with the meaning of convergence of every consumer to a type-scheme, but rather with the meaning that it is possible in every Country to find similar behaviour phenomena in the consumptions (of course at different levels of intensity and diffusion).

\section{Innovation in Agro-food}

\subsection{Innovation for Agro-food Quality and Sustainability}

What is more important to highlight in the present work is the growing reinforcement of the link among innovative phenomena, agro-food and sustainable developmente. Such link, actually, can be analyzed from two different points of view. From one side, the turning to innovation as animation factor for sustainability in the agro-food sector is pursued to assure the social-economical and environmental sustainability of the sector itself, from the other side, to make that the sector contributes to the maintaining in time and space of economical, social and environmental conditions, which determine the human development in the complex and, then, not only the development of one specific sector. The increased consumers' sensitivity to themes of health, enviroment or equity and the relative research of an improvement of wellness and quality of life, have stimulated a growing interest to the complex of activities to start not only with the purpose of orienting company more and more to society, but also to create a company vision strictly linked to a humanitarian, social or environmental engagement.

If from one side such orientations constitute real incentives of innovation, from the other side they have determined an evolution of agro-food system which has more and more expected strategies of production, of logistic and distribution, as well as of innovative information and communication, inspired to principles of sustainability and marked by a strong orientation to responsibility.

The evolutive process which is at present interesting the agro-food sector, thus, today sees the innovation as the principal lever to guarantee a sustainable development of sector and in its referring system. First of all, the strong connection between competitivity and innovation constitutes a warranty for a sustainable economical development of agro-food sector, because it allows to let last in time the capacity of aquisition of competitive advantages either of first mover or of holders of specific and new skills and knowledges (Knudson et al., 2004).

In social terms, the inclusivity of innovation pushes then to a widespread diffusion of innovation themselves in agro-food field either among companies (as holder of growing opportunities) or among consumers (who can benefit from a constant reduction of prices and a lower cost for acquiring information about health, about production environment or about referring territories).

In environmental terms, at last, the process of greening, started by Communitarian Agricultural Politics and sustained by the progressive integration of environmental politics in the development of farm and food sector, recognizes just in innovation the turn-key to assure in time and space the intactness of natural factors, of environmental and landscape resources. It deals about factors that take shape as real primar goods for the agro-food company and that add the relative products of meaning (Detre et al., 2011).

In this point of view, innovation, guaranteeing the decrease of production costs or of environmental impact, the increase of availability of long-period capital as well as of market fee, introduces itself as real tool for sustainability of internal and external processes of company, of its relations with market, with consumers and with society in its whole. Actually, relatively to the agro-food sector, the application of innovation concept is suitable for several 
interpretations. Interesting the whole system, such innovations are the result of scientific progresses in agro-bio-technological field (turned for example to increase the global food resources but offering to farmers opportunitie of protection and improvement of harvest, together with a more efficient use of natural resources), in food field (turned for example to improve the diet of elderly people or of people with disabilities), in environmental field, but also in logistic and communication field. Thus, from the genetically modified organisms to functional food we can go to precision agriculture, to development of modern information and communication technologies in the different productive sectors and, then, to a vision of the sector in constant evolution or, better said, "revolution".

In such a context, the innovative company makes its way more and more, and revises its own management phylosophy in the light of a new mission based on society and oriented to satisfying common general interests. The goods' production, the services' provision and the innovation development, then, are all tended to satisfying values, needs and desiders expressed by society and consumers. It deals actually of an orientation witnessed by multiplication at global level of actions and plans implemented by companies to supply a contribution with a social cause, in the sphere of pursuing an objective even if commercial.

Not by chance, the health crisis, and the food scandals, which in the last years have interested the agro-food sector, have significantly had an effect on public opinion, creating a widespread worry about quality, health and about certainty of products themselves. At the same time, the strong connection existing between health and food, the impact of agricultural activity on environment, the familiarity and interdependence of products with production territory require to operators agro-food supply chain, to evaluate the incentives and requests coming from demand, above all in term of greater aethicity either of products or of company strategies (Briamonte, Hinna, 2008).

In the perspective of innovation, quality of agro-food products, then, must not be referred only to nutritional, sensorial, organolectic and hygienic-health aspects, traditionally considered, buti t must be interpreted in a wider meaning which considers environmental, social, cultural and territorial aspects. It is derived, then, that, with reference to advanced countries' referring markets, the quality concept is to be understood as a whole of values, referring to a quantity of different attributes, each of which assumes a greater or lower importance, depending on the type of product, and of segment, or on the niche market to which it is destined (Carbone, 2006). The combination of these values brings back to a consumption demand more and more critical, demanding and distinguished, which constitutes the fundamental engine of sustainable innovation in agro-food sector (Esposti, 2005).

Starting from this principle, and in consideration of the recent tendencies of food demand, it is possible to identify some developments' directions of quality demand expressed by consumer, able to generate innovative ferment in agro-food sector: Healthy living, understood as affirmation of a healthy life style: Convenience as a way of life and Sympathetic food production which refer to the way food is produced and to used production technologies, till $3 D$ food, that is "printed" food, for medical purposes.

Referring to the first tendency, undoubtedly, the increase of life expectations, the increases of health costs linked to a greater onset of pathologies linked to wrong food habits, the research of better quality standards, have determined a significative change in food demand more and more oriented to products with strong health features (Banterle, Cavaliere, 2009; Carbone, 2006; Verbeke, 2006).

Consequently, in food industry have caught on experimentation and use of innovative technologies, aimed to realization of specific products such as products light, low-calories and functional foods, which represent today a market in very quick evolution, either in international context or national one (Bech-Larsen, Scholderer, 2007; Verbeke, 2006; Sirò et al., 2008).

With reference to the second direction, the greatest woman participation to work market and the evolution of family characteristics, have contributed to affirm a new type of demand time saving oriented, that is, to food that allows che consumer to satisfy the primar exigencies and, at the same time, to save time for purchases, preparation and food consumption. Such orientation has favoured the intensification of investments in research and innovation in food industry, at support of so called convenience food, that is product which allow a considerable saving of time in the various steps of purchase, preparation and consumption process.

As regards the third direction, in the last years, consumption models have affirmed which have as common denominator the way of good's choice, which takes under consideration the social and environmental effects of product's life cycle, being different from the simple utilitarian consumption, because they attribute value to other product's components, with particular reference to the consequences or the effects of its production or commercialization on the environment and collective wellness (Briamonte, Hinna, 2008). In this sense, the innovative efforts in agro-food sector are addressed to the identification of products and processes able to combine 
economical, environmental and social aspects of sustainability.

At last, with reference to the fourth direction, it has already been undrlined as, above all in Europe, population is getting older. In 2010, in fact, about $17 \%$ of population was 65 or more. This number is destined to increase to $30 \%$ of population within 2060. The whole social system, but also the economical one, has to adapt to this change. In the sphere of a communitarian plan, called Performance, the European Union has thought to develop an industrial process for production of food suitable for elderly or with health problems people. A course, then, to improve their life quality. The processi is grounded just on 3D print of healthy food, such as meat and vegetables, whose molecular structures would be printed by particular printers and made softer and easier to digest for people with health problems who, usually, suffer from dysphagia and malnutrition.

\subsection{The Innovation Challenges for Agro-food Stystem}

Köhler affirm that the public perception is very important for the progress of a new technology; in fact, every new technology has a different impact on population and this depende on vary factor, included those cultural and environmental ones (Köhler, Som, 2008).

The acceptance of the consumer, then, is crucial for success of food products (MacFie, 2007) and safety of food products represents a fundamental quality element: health is today as important as taste (Roininen et al., 2001). The evaluation from the citizen's acceptance towards technologies in food fiels has a strategic value: the attitude to the innovations in food sector has then economical, social and political influences.

Reactions to specific applications, however, can differ from country to country and depend on traditions which characterize the singular country and on the trust in capacity of public authorities in assuring consumer's protection; even when consumers have the possibility to go in depth into different aspects linked to technologies (ex. Social and environmental), are always those related to food health and its connections with human health to play the principal role (Bieberstein et al., 2012).

It is interesting to understand, then, the role that investments in research and development have in Italian agro-food sector. On this subject, it is necessary to underline that competitivity of the sector on almost global market requires a recovery of efficiency, productivity, organization of supply chain that, on its turn, suggests a huge investment in research and innovation.

The particularity of this sector (companies of little dimensions, operating in competitive regime, the political-strategic importance of food supply), explains how research and experimentation are largely financed by pubic subjects.

The agro-food is a sector at low levels of research and development intensity, if compared with other industrial sectors, and in Italy the role of public reserch in favour of the agro-food seems to replace completely in the absence of research in the primar sector and to a weak level of investment in research of food industries which very often own short capacity of adopting innovative strategies. The question results to be even more un favourable if we consider that agriculture uses research already developed in other sectors.

As regards the spread of innovations, in agriculture the service of agricultural development (SSA) are used. With this word various activities are grouped (research, formation, consultancy) turned to substain incomes, employement and wellness in farm areas and in linked zones, as well as to improve quality and safety of food in favour of consumers. Since long time, such activities are considered as a collective interest and then object of public support.

Then, most of innovations appeared in agro-food field do not derive from inside the sector, but come from the application and transformation of results of research led in other spheres as, for example, has happened with the automation of processes, the activity of results' control, above all in terms of quality.

In particular, in the situation of Italian food industry, innovation acts on:

- $\quad$ Production costs (process and organizative innovation);

- $\quad$ Costs and revenues (process innovation if company enters a new market);

- $\quad$ Products' differentiation (product's innovation).

The innovative proces, however, is not grounded exclusively on quantity of $\mathrm{R} \& \mathrm{~S}$ produced by a company, but it is build thanks to the relationships that the company establishes with the external environment (Galende, de la Fuente, 2003). In particulare, it is necessary to underline the type of relationship that is developen between company and environment, trying to catch the essential and determining elements for its own success.

The modern food market is, then, a market more and more characterized by a high level of innovation, which is 
consequence of expectations more and more different from the consumers, no more tied exclusively to the physiological/nutritional aspect (moved just by appetite), but also to different edonistic desires, like to keep fit and healthy, to increase vital forces, to spare time, or to respect environment. New macro tendencies in consumption, whose sources are changes in level and distribution of income (Mruk, 2007), as well as the internal conditionings of purchasers have so a significant impact on their purchase behaviours.

On the other hand, there are many individual conditionings which determine the purchase behaviours: personal (age, cycle of family life, gender, education level, financial status, health condition), psychological (motivations, perceptions, past experience, tastes, character), social and cultural (social roles, belonging groups, religion, environment, origins, tradition) (Gatignon, Robertson, 1991; Rogers, 1995; Steenkamp et al., 1999; Michon et al., 2010). This interests above all the young consumers, who allow the offer's etension of companies (Capitanio et al., 2009). From this, the necessity of orienting the interest of studies about consumer's behaviour to the innovation bent (consumer innovativeness).

\subsection{Propensity to Innovation in Consumer Behaviour: La Consumer Innovativeness}

Given a continuous process of "enrichment", the food products are conceived more and more according to the integrated point of view of product/service; they represent the declination of a new food concept destined to perform the most evoluted and complex use function meal solution rather than to the traditional use function of simple ingredient of one meal component. In such a context, new products at high technological content enter the market, capturing a growing attention from the consumers and being called more and more vividly for the agro-food industry, which is called to tune offers' formulations able to be suitable to the new and more comples orientations of consumption (Goldsmith, Hofacker, 1991; Grewal et al., 2000; Goldsmith, 2001).

Facing such evolutions, the analysis of food consumption's behaviour, despite the developments and theoretical progresses which have interested in the last years the general theory of consumer behaviour, still serves significan interpretative limits (Dagevos, 2005). These can be brought back, from one side, to the little attention reserved to the study of food behaviours linked to consumption of innovative products, and, from the other side, to the stressed preference for the use of analysis methodologies still deeply anchored to the most traditional setups of classical economy (Becker, 2004).

The still emerging nature of business of agro-food products at high technological content and the specific connotation of the product make, then, particularly interesting to deepen above all in the empiric dimension the understanding of choice determinings below the consumption of such food and the consumption's functions referring to them.

In the course of the last decades, in fact, the study of consumer's behaviour has been interested by a frantic and renewed debate under the incentive of new theoretical formulations which have interested the marketing discipline. We are referring, in particular, to the recently developed theoretical acquisitions, in a separated way but with strong characters of connection, from the theory of relational marketing with its recalls to continuity improvement and personalization of exchange relationships, from the experiencing approach with the particular interest attributed to the emotive and affective component (Pine, Gilmore, 2000; Addis, Holbrook, 2001) and, not last, from aethical marketing and its enlargement to social and collective dimension of consumption processes (Kotler et al., 2002).

Such evolution, even if they have not generated a unitarian theoretical body and proposed a shared analysis model, tend to supply, in the variety of proposed formulations, a more integral application and next to evolutions of consumption reality. The recalled perspectives, mastering some of the theoretical considerations of traditional approaches and in particular of cognitive school, even in their different shade propose as theoretical progresseso at least two fundamental acquisitions.

The first regards the processual dimension in whose context must necessarily be put the consumer behaviour. According to this point of view, the exchange loses its dimension of punctual event completely escaped from the variable time to assume that of complex activity defined on the base of specific time divisions characterized by a plurality of actions, of subjects and of activated relationships.

The declination of processual dimension, developed in particular from the experience approach, introduces to the second dimension of analysis represented by the multidimensionality of purchase/consumption processes. According to this approach, consumption is seen as "holistic" experience of consumer, result of integration of sensorial (sense) affective (feel) cognitive (think), behaviour (act) and social (social) experiences (Schmitt, 1999), in which are involved many different aspects of its being as individual and of its social-cultural context. The attention moves from the analysis of singular purchase acts and of decisional processes that lead their choices to the analysis of experience 
dimension of consumption and of the general context in which it realizes itself. Starting from these premises, many studies have investigated the behaviour of purchase/consumption in the empiric dimension with a stronger focus on those categories of products which are characterized for a more typically emotive content and for a subjective and intimate involvement, to come closer only more recently to more "utilitaristic" products' categories.

In this last statistic it is possible to take back the analysis of food consumption that, even remaining in many cases an exclusive stronghold of some study spheres referring particularly to farm economy, in general, goes more and more to the contamination of categories of declared analysis in the circle of new theories of social studies (Becker, 2004).

The food demand, even tied to satisfaction of primar needs (diet and subsistence), is recognized as expression of much more articulated exigencies and needs, with which the use function is enriched and it is declined according to new contents which refer more directly to factors tied to the world of sociality, of relationships, of values, of emotions and sensations, etc. (Dagevos, 2005). As it has been underlined, the functional quality (expressions of use characteristics specific of the product) and the price, even representing a set of variables of still modern validity in formulation of process of food consumption, do not exhaust entirely their interpretative efficiency. In fact, they limiti their application sphere exclusively to some process activities - those of purchase and in particular of choice formulation - completely overlooking the exploration of the aspects tied to use and to reactions linked to them (Dagevos, 2005).

The food consumption takes on the dimension of complex phenomenon where cognitive-rational motivations are translated and reinterpreted on the base of more articulted social and emotional dynamics and, therefore, the individuation itself of variables which condition its formation can not be limited to a singular activity, but extendes to every activity, and regards not only directly what and where one purchases, but also when and how one utilizes what has purchased, that is the specific situations and experiences of purchase/consumption in variety and variability in which they can appear (Kaushik, Rahman, 2014).

Then, into this context has got the bent to innnovation as central theme of consumer behaviour (consumer innovativeness), theme which has caught on in about the first half of Nineties either in the studies or in the marketing practices of new products or as valid interpretative key for comprehension and explanation of early adoption, though the relation between profiles of consumers' personality and product's innovation has its roots in previous studies of marketing and consumptions' psychology that date in the first Seventies (Barrena Figueroa, López de Meneses, 2013). The traditional studies have focused in particular on the individuation of personality characteristics of iniziators, consumers with a greater innovative bent who are the first to adopt the new products available in the distribution, referring in the most sophisticated theoretical constructions even to the contingent and situational determinants (Midgley, Bowling, 1978). The theorists contingency, then, individuate an abstract set of personality tracts operationalized which woud determine the degree to innovation bent from the consumers. The empiristic studies, developed in opposition, have induced to a rationalization of the contingent theory, identifying a correlation between the consumers' innovative behaviour and a set of five personal tracts/attributes of cognitive/behaviour character: categories' width, flexibility, ambiguity tolerance, self-respect and research of emotions (Goldsmith, 1989). Nowadays the theoretical and empirical studies related to consumers' innovation bent present the problem of a relevant words confusion and some researches (Foxall, 1995) have highlighted, in particular, how the consumer's behaviour, with regard to the innovative variable, can change in relation to the product's types and to the distributive forms' types, adopted for the launch of the new product.

In such a scenario, the consumer is as free as confused, disoriented by the qualitative multiplicities of food and diet offer in general, and this determines not rational purchase behaviours. That's the explanation of the difficult reading of studies about consumer's behaviour towards the food products' inovation, because of the complexity of consumers' attitudes and reactions towards innovation, as well as, preliminarly, because of their subjectivity in defining innovations themselves, that is what is considered innovative.

\section{Conclusions}

The deep changes intervened in the life and work system of consumers, the social-economical changes deriving from an increase of pro-capite income, as well as the succeeding each other of various events that have made the history of the agro-food in the last years, have stimulated new behaviours of consumption with regard to the traditional habits, marking a decisive turning-point in the approach of consumers to services and products of food offer. The greater attention to dietistic-healthy aspects, the personalization of food styles, the destructuration of meals, are only some of the terms which by then qualify unequivocally the food products' demand and which it is impossible not to take into consideration in any approach to the system. In opposition to the so emphatized "homologation" of purchase behaviours, the personalization of life and food styles corresponds to the influence that the consumer suffers from the 
social-demographic , cultural and geographic factors; examples of this are the return and/or reapproach to the values of rural world, the demand of ethnical products and of equo-solidal commerce, the more and more intense attention to food quality and safety, the spread of "bio" culture.

The evolutive process which nowadays is interesting the agro-food sector, then, sees innovation as the main lever to guarantee a sustainable development of sector and in its referring system. Thus, for example, is from one side the interest grows, at scientific besides institutional and productive level, for products such as, for example, functional foods that have the purpose of optimize the physical wellness and reduce the risk of diseases, from the other side, more and more the debate has started about the possible solutions coming in a more incisive way from the modern biotechnologies, by nanotechnologie, and by the use of 3D print. Such interests make possible that the goods' production and the services' performance are all shown in the satisfaction of values, needs and desires expressed by society and by modern consumers. This is witnessed by multiplication at global level of actions and plans implemented by companies to supply a contribution to a healthy cause and that see involved the different company's functions: from production to distribution and to marketing until the various forms in which the company carries put its role of territorial agent.

So, the care for health, the respecto for environment and territory, the interest for quality products are the principal worries of the modern society and these, as previously described, can be considered even as driver for the activation of innovative processes in the agro-food companies. But the developmente routes which are characterizing the agro-food sector are different if not opposed: strong tie to tradition and territory or hi-tech food with new products realized through the use of genetical modifications of bio/nanotechnologies.

The analysis of consumer's behaviour on the food market, stood out from the study of literature (national and international) developed in the present work, shows how it is involved, from one side, by the physiological need (and then by the mere sensation of appetite) and by their own habits of use, from the other side, by the impact of specific factors of marketing (sometime agro-food), such as the conditions of social, cultural and economical environment. In this sense, the consumers expect from food: vitality, health, beauty, growth of consumption's pleasure (Gutowska, Ozimek, 2005).

The modern consumer of food products results, thus, to be characterized by:

- choice of productors who use different technologies;

- different levels of education and experiences with other cultures, among which nationl and local food;

- progressive diversification in the sphere of expectations towards food;

- $\quad$ growing interest to food which favours health, beauty, physical condition;

- growing interest to rules of the so called "rational nutrition" and awareness to inforation sources about food;

- progressive increase of specific segments of consumers who distinguish themselves on the ground of new criteria;

- variations in income's levels which contribute to increase the exigencies and a higher

- acceptability of innovative solutions;

- greater awareness of consumers inside a legal protection of their interests.

In consideration of all these factors, as the behaviours of consumers and other market operators are significantly changed (Wiatek-Kubiak, Balcerowicz, 2009), the companies compete to satisfy their preferences through innovation. In conditions of necessity of quick reactions for exigencies dictated by a dynamic market, the knowledge of attitudes and behaviours of consumers towards innovation can contribute mainly to the growth of innovativity of the subjects themselves.

In conclusion, the literature analysis developed in the present work takes us to affirm that, though the principal innovations in being are oriented above all on the elderly persons, it is on young consumers that it is necessary to point because, independently from the underlined elements, they are generally opener to newness, even if the speed of acceptance of innovations is different according to the country of birth. In fact, they impose high requirements to food producers and are aware consumers, because they know what to expect from a new product.

The young, then, accept with greater easiness the innovative products, and that is why such segment should be taken under consideration by the marketing specialists in their promotion activities. But to be able to reach young consumers, it is important to know their attitude and behaviours, and this will allow to reach them with specific (and suitable) marketing activities. Consequently, such activities will have effect on success or failure of the launch of a 
new innovative product on the food market.

The trend which is changing the attitude in creating products will be constituted by changes in consumer's behaviour, but above all by the necessity of including such changes in innovation process.

A possibility of research that can start from the developed analysis in the present work, that does not claim to be exhaustive, could be based just on the research of key factors which drive (or determine) actually the young consumers in the choice of an innovative agro-food product (such as for example edonism, convenience, brand, etc).

Internet has changed the purchase process of consumer either directly through e-commerce actions or indirectly allowing possible pieces of information that previously were very rare and expensive.

Among the factors which have produced this change are included: the enabling conditions, the attitudes toward technology, the purchase culture and experience levels in Internet. The enabling conditions regard the access possibilities to Internet, the knowledge of English language, the low cost of web connection and the slightest knowing of use.

Another condition regards the attitude towards technology.

Three principal variables influence such attitude: the motivation to use of computer, the income level and the optimistic or pessimistic orientation to technologies.

Another factor is the purchase culture that influences the approval or less towards the distance transactions. Buying online means to give up the direct and physical preventive control on products and sellers.

Another aspect regards the social relation of the purchase; when the purchase represents a fundamental moment of social relationship or use of free time, one tends to privilege the traditional behaviour rather than the online one.

Even the experience level affects the online purchase: the network beginners tend to assume a more casual and explorative use behaviour, while the experts are more oriented to assume a punctual research behaviour in the information collection.

But the principal change produced by Internet is the access to information. The purchases, in fact, are more and more grounded on the available information and on their usability. In comparison to the traditional purchase process, Internet intervenes in the purchase process through three influence levels:

1) Modification of informative collection in the traditional process

2) Creation of integrated purchase processes

3) Purchase processes wholly online developed.

1) The access to the Network introduces elements of originality in the purchase behaviour of the consumer, who can enter a great availability of data about products, brands and producers. The information can derive either from official sources, promoted by companies, or from non official, personal or group, sources.

2) Another way with which Internet intervenes in the online purchase processes is through the integration of online and offline steps, so that to easen the purchaser and to reduce the difficulties that a wholly virtual process can bring. In case of complex purchases or where the physical experience is important, it can happen that consumer turns to more traditional purchase methods, thus reducing the cultural and experience barriers. In several examples of integrated processes to consumers is entrusted also the function of co-planning.

3) The purchase process can develop even directly online according to prearranged procedures and governed by a substantially rational attitude.

\section{References}

Addis, M., \& Holbrook, M.B. (2001). On the conceptual link between Mass Customization and Experiential Consumption: An Explosion of Subjectivity. Journal of Consumer Behaviour, 1(1), 50-66. https://doi.org/10.1002/cb.53

Backstrom, A., Pirttila-Backman, A.M., \& Tuorila, H. (2004). Willingness to try new foods as predicted by social representations and attitude and trait scales. Appetite, 43(1), 75-83. https://doi.org/10.1016/j.appet.2004.03.004

Banterle, A., \& Cavaliere, A. (2009), Determinanti socio-economiche dell'obesità. Agriregionieuropa, 5(19). Retrieved from http://agriregionieuropa.univpm.it/pdf.php?id_articolo=520

Banterle, A., Cavaliere, A., Carraresi, L., \& Stranieri, S. (2011). Innovativeness in food small business: what is its relationship with marketing?. Agr Econ, 57(10), 474-483. 
Baregheh, A., Rowley, J., \& Sambrook, S. (2009). Towards a multidisciplinary definition of innovation. J Manage Decis, 47(8), 1323-1339. https://doi.org/10.1108/00251740910984578

Barrena, Figuero, M.R., \& Lopez, De Meneses T.G. (2013). The effect of consumer innovativeness in the acceptance of a new food product. An application for the coffee market in Spain. Spanish Journal of Agricultural Research, 11(3), 578-592. https://doi.org/10.5424/sjar/2013113-3903

Bech-Larsen, T., \& Scholderer, J. (2007). Functional foods in Europe: Consumer research, market experiences and regulatory aspects. Trends Food Science Technologies, 18, 231-234. https://doi.org/10.1016/j.tifs.2006.12.006

Becker, T. (2004). Consumer Behaviour research in the advent of 21st Century paper presented at Food Consumption Behaviour, Copenhagen, Denmark16-17 November.

Bellows, A.C., Alcaraz, G., \& Hallman, W.K. (2010). Gender and food, a study of attitudes in the USA towards organic, local, US grown, and GM-free foods. Appetite, 55(3), 540-550. https://doi.org/10.1016/j.appet.2010.09.002

Bieberstein, A., Roosen, J., Marette, S., Blanchemanchel, S., \& Vandermoere, F. (2013). Consumer choices for nano-food and nano-packaging in France and Germany. European Review of Agricultural Economics, 40(1), 73-94. https://doi.org/10.1093/erae/jbr069

Briamonte, L., \& Hinna, L. (2008). La responsabilità sociale delle imprese del sistema agroalimentare. Studi e Ricerche Inea, Roma, Italy.

Capitanio, F., Coppola, A., \& Pascucci, S. (2009). Indications for drivers of innovation in the food sector. British Food Journal, 111(8), pp. 820-838. https://doi.org/10.1108/00070700910980946

Carbone, A. (2006). La valorizzazione della qualità agroalimentare: diverse strategie a confronto. Agriregionieuropa, 2(5). Retrieved from http://agriregionieuropa.univpm.it/dettart.php?id_articolo=113

Censis. (1994). Dopo il consumo affluente, la medietà. Censis-Findomestic, dattiloscritto, Roma, 18 ottobre.

Clark, R.A., \& Goldsmith, R.E. (2006). Interpersonal influence and consumer innovativeness. International Journal of Consumer Studies, 30(1), 34-43. https://doi.org/10.1111/j.1470-6431.2005.00435.x

Costa, A.I.A., Dekker, M., \& Jongen, W.M.F. (2004). An overview of means-end theory: potential application in consumeroriented consumeroriented food product design. Trends in Food Science and Technology, 15(7-8), 403-415. https://doi.org/10.1016/j.tifs.2004.02.005

Cotte, J., \& Stacy, W. (2004). Families and Innovative Consumer Behavior: A Triadic Study of Siblings and Parents. Journal of Consumer Research, 31(1), 78-86. https://doi.org/10.1086/383425

Dagevos, H. (2005). Consumers as four face creatures. Looking at food consumption fron the perspective of contemporary consumers. Appetite, 45(1), 32-39. https://doi.org/10.1016/j.appet.2005.03.006

Detre, J.D., Johnson, A.J., \& Gray, A.W. (2011). Innovativeness and Innovation: Implications for the Renewable Materials Supply Chain. Int. Food Agribusiness Manag. Rev., 14(2), 17-34. Retrieved from https://www.ifama.org/publications/journal/vol14/cmsdocs/20110051_Formatted.pdf

Dobre, C., Dragomir, A., \& Preda, G. (2009). Consumer innovativeness: a marketing approach. Management \& Marketing, 4(2), 19-34.

Dobson, A., \& Bell, D. (2006). Environmental Citizenship. Cambridge, Massachusetts: The MIT Press.

Esposti, R. (2005). Cibo e tecnologia: scenari di produzione e consumo alimentare tra tradizione, convenienza e funzione. Agriregionieuropa, 1(3). Retrieved from http://agriregionieuropa.univpm.it/dettart.php?id_articolo=81

Fortuin, F.T.J.M., \& Omta, S.W.F. (2009). Innovation drivers and barriers in food processing. British Food Journal, 111(8), 839-851. https://doi.org/10.1108/00070700910980955

Fotopoulos, C., Krystallis, A., \& Ness, M. (2003). Wine produced by organic grapes in Greece: using means-end chains analysis to reveal organic buyers' purchasing motives in comparison to the non-buyers. Food Quality and Preference, 14(7), 549-566. https://doi.org/10.1016/S0950-3293(02)00130-1

Galende, J., \& De La Fuente, J.M. (2003). Internal factors determining a firms' innovative behaviour. Research Policy, 32(5), 715-736. https://doi.org/10.1016/S0048-7333(02)00082-3

Gatignon, H., \& Robertson, T.S. (1991). Innovative decision processes. In Robertson, T.S., \& Kassarjian, H.S., (Eds.), Handbook of Consumer Behavior. Prentice-Hall, Englewood Cliffs, NJ, USA. 
Goldsmith, R.E. (1989). Adapators and Innovators: Styles of Creativityu and Problem Solving. Routledge, London.

Goldsmith, R.E. (2001). Using the domain specific innovativeness scale to identify innovative internet consumers. Internet Res, 11(2), 149-158. https://doi.org/10.1108/10662240110695098

Goldsmith, R.E., \& Hofacker, C.F. (1991). Measuring consumer innovativeness. Journal of Academic Marketing Science, 19(3), 209-221. https://doi.org/10.1007/BF02726497

Goldsmith, R.E., d'Hauteville, F., \& Flynn, L.R. (1998). Theory and measurement of consumer innovativeness: a transnational evaluation. European Journal of Marketing, 32(3/4), 340-353. https://doi.org/10.1108/03090569810204634

Grunert, K.G., Jensen, B.B., Sonne, A.M., Brunso, K., Byrne, D.V., Clausen, C., ... Scholderer, J. (2008). User-oriented innovation in the food sector: relevant streams of research and an agenda for future work. Trends in Food Science \& Technology, 19(11), 590-602. https://doi.org/10.1016/j.tifs.2008.03.008

Gutkowska, K., \& Ozimek, I. (2005). Wybrane aspekty zachowan konsumentów na rynku zywnosci - kryteria róznicowania, SGGW, Warszawa.

Hirunyawipada, Tanawat, \& Paswan, A.K. (2006). Consumer Innovativeness and Perceived Risk: Implications for High Technology Product Adoption. Journal of Consumer Marketing, 23(4), 182-198. https://doi.org/10.1108/07363760610674310

Huotilainen, A., Pirttila-Backman, A.M., \& Tuorila, H. (2006). How innovativeness relates to social representation of new foods and to the willingness to try and use such foods. Food Quality and Preference, 17(5), 353-361. https://doi.org/10.1016/j.foodqual.2005.04.005

Im, S., Bayus, B.L., \& Mason, C.H. (2003). An Empirical Study of Innate Consumer Innovativeness, Personal Characteristics, and New-Product Adoption Behavior. Journal of the Academy of Marketing Science, 31(1), 61-73. https://doi.org/10.1177/0092070302238602

Im, S., Mason, C.H., \& Houston, M.B. (2007). Does Innate Consumer Innovativeness Related to New Product/Service Adoption Behavior? The Intervening Role of Social Learning via Vicarious Innovativeness. Journal of Academy Marketing Science, 35, 63-75. https://doi.org/10.1007/s11747-006-0007-z

Jackson, T. (2009). Prosperity Without Growth: Economics for a Finite Planet. Routledge.

Kaushik, A.K., \& Rahman, Z. (2014). Perspectives and Dimensions of Consumer Innovativeness: A Literature Review and Future Agenda. Journal of International Consumer Marketing, 26(3), 239-263. https://doi.org/10.1080/08961530.2014.893150

Knudson, W., Wysocki, A., Champagne, J., \& Peterson, H.C. (2004). Entrepreneurship and Innovation in the Agri-Food System. American Journal of Agricoltural Economics, 86(5), 1330-1336. https://doi.org/10.1111/j.0002-9092.2004.00685.x

Kohler, A.R., \& Som, C. (2008). Environmental and Health Implications of Nanotechnology-Have Innovators Learned the Lessons from Past Experiences? Human and Ecological Risk Assessment: An International Journal, 14(3), 512-531. https://doi.org/10.1080/10807030802071812

Kotler, P., Ned, R., \& Lee, N. (2002). Social Marketing: Improving the Quality of Life. Sage Publishing.

Kuhne, B., Vanhonacker, F., Gellynck, X., \& Verbeke, W. (2010). Innovation in traditional food products in Europe: Do sector innovation activities match consumers' acceptance?. Food Quality and Preference, 21(6), 629-638. https://doi.org/10.1016/j.foodqual.2010.03.013

Macfie, H. (2007). Consumer-led food product development. Cambridge, UK: Woodhead. https://doi.org/10.1201/9781439823903

Malassis, L., \& Padilla, M. (1986). Economie agro-alimentaire. III. L'economie mondiale. Cujas, Paris.

Michon, C., O'Sullivan, M.G., Sheehan, E., Delahunty, C.M., \& Kerry, J.P. (2010). Study on the influence of age, gender and familiarity with the product on the acceptance of vegetal soups. Food Quality and Preference, 21(5), 478-488. https://doi.org/10.1016/j.foodqual.2010.01.003

Midgley, D.F., \& Dowling, G.R. (1978). Innovativeness: the concept and its measurement. Journal of Consumer Research, 4(4), 229-242. https://doi.org/10.1086/208701

Miele, M., \& Parisi, V. (2000). Consumer concerns about animal welfare and food choice. Italian report on 
laddering interviews Dept Agr Econ, University of Pisa, Pisa, Italy.

Mruk, H. (2007). Makrotrendy a zachowania konsumentów. In Z. Kedzior (Ed.), Konsument. - Gospodarstwo domowe.- Rynek, Centrum Badan i Ekspertyz, AE Katowice, Katowice.

Naidoo, V. (2010). Firm survival through a crisis: the influence of market orientation, marketing innovation and business strategy. Indust Marketing Manage, 39(8), 1311-1320. https://doi.org/10.1016/j.indmarman.2010.02.005

Padilla, M. (1992). Le concept de modèle de consommation alimentaire et la théorie de la consummation. Economies et Sociétés, Série Développement Agroalimentaire, AG n.21, juin.

Pine, E.G. (2000). L'economia dell'esperienza. Etas, Milano.

Roehrich, G. (2004). Consumer innovativeness: concepts and measurements. Journal of Business Research, 57(6), 671-677. https://doi.org/10.1016/S0148-2963(02)00311-9

Rogers, E.M. (1995). Diffusion of Innovations (4th ed.) The Free Press, NY.

Roininen, K., Tuorila, H., Zandstra, E.H., De Graaf, C., \& Vehkalahti, K. (2001). Differences in health and taste attitudes and reported behaviour among Finnish, Dutch, and British consumers: A crossnational validation of the Health and Taste attitude scales (HTAS). Appetite, 37(1), 33-45. https://doi.org/10.1006/appe.2001.0414

Ruvio, A., \& Shoham, A. (2007). Innovativeness, exploratory behavior, market mavenship, and opinion leadership: An empirical examination in the Asian context. Psychology and Marketing, 24(7), 703-722. https://doi.org/10.1002/mar.20180

Sabbadin, E. (1990). Nuove tendenze nel comportamento di acquisto del consumatore. Commercio, (36), 9-29.

Seyfang, G. (2006). Ecological citizenship and sustainable consumption: examining local organic food networks. Journal of Rural Studies, 22(4), 383-395. https://doi.org/10.1016/j.jrurstud.2006.01.003

Sirò, I., Kapolna, S., Kapolna, B., \& Lugasi, A. (2008). Functional food. Product development, marketing and consumer acceptance: a review. Appetite, 51(3), 456-467. https://doi.org/10.1016/j.appet.2008.05.060

Steenkamp, J.B.E.M., \& Burgess, S.M. (2002). Optimum stimulation level and exploratory consumer behavior in an emerging consumer market. International Journal of Research in Marketing, 19(2), 131-150. https://doi.org/10.1016/S0167-8116(02)00063-0

Steenkamp, J.B.E.M., Ter Hofstede, F., \& Wedel, M. (1999). A crossnational investigation into the individual and national cultural antecedents of consumer innovativeness. Journal of Marketing, 63(2), 55-69. https://doi.org/10.2307/1251945

Summers, J.O. (1971). Generalized Change Agents and Innovativeness. Journal of Marketing Research, 8, 313-316. https://doi.org/10.2307/3149568

Urala, N., \& Laahteenmaki, L. (2007). Consumers' changing attitudes towards functional foods. Food Quality and Preference, 18, 1-12. https://doi.org/10.1016/j.foodqual.2005.06.007

Venkatraman, M.P. (1991). The impact of innovativeness and innovation type on adoption. Journal of Retailing, 67(1), 51-67.

Verbeke, W. (2006). Functional foods: Consumer willingness to compromise on taste for health?. Food Quality and Preference, 17(1-2), 126-131. https://doi.org/10.1016/j.foodqual.2005.03.003

Wang, H., Pallister, J., \& Foxall, G. (2006). Innovativeness and involvement as determinants of website loyalty. A test of the style. Involvement model in the context of Internet buying. Technovation, 26(12), 1357-1365. https://doi.org/10.1016/j.technovation.2005.11.004

Wiazek-Kubiak, A., \& Balcerowicz, E. (2009). Determinanty rozwoju innowacyjnosci firmy w kontekscie poziomu wyksztascenia pracowników, PARP, Warszawa. 